\title{
Autumn Mule Deer Foods on Heavily Grazed Cattle Ranges in Northwestern Colorado
}

\author{
GARY C. LUCICH AND RICHARD M. HANSEN
}

\begin{abstract}
The botanical composition of the diets of domestic cattle and mule deer (Odocoileus hemionus) was estimated by microscopically examining fecal samples collected on deer winter ranges heavily used by cattle. Diet overlap ranged from 1 to $22 \%$ ( $\mathrm{x}=$ $12 \%$ ) on the nine areas studied. When cattle are forced from a grass dominated diet to browse forage on overgrazed ranges, diet overlap and therefore forage competition increases between deer and cattle.
\end{abstract}

The effects of excessive livestock use on the winter range of mule deer continues to be controversial in the Rocky Mountain Region, especially since less than $50 \%$ as many deer are harvested now as were 20 years ago. Recent literature suggests that diet overlap of domestic cattle and mule deer in northwestern Colorao was about 4\% in 1975 (Hubbard and Hansen 1976; Hansen and Clark 1977; Hansen et al. 1977). Many wildlife biologists believe dietary overlap between mule deer and cattle should be much higher and some literature published 20 to 40 years ago supports this contention (Robinson 1931, 1973; Interstate Deer Herd Committee 1947).

An objective of this study was to select mule deer wintering sites which appeared to have been continuously abused by livestock for many years, and to determine early winter foods selected by mule deer and cattle on these same sites. We hypothesized that in these extreme cases, diet overlap would be higher than on ranges in better condition.

\section{Methods}

Nine areas approximately $0.5 \mathrm{~km}^{2}$ in size on mule deer winter range on the western slope of the Rocky Mountains in northwestern Colorado were chosen according to the appearance of vegetation and the amount of bare ground. Ten fresh defecations were collected for both mule deer and cattle on each area during the period from September to December, 1976. One diet was estimated for each herbivore on each area by compositing the 10 defecations. Five microscope slides were made from each composite sample and 20 microscope fields per slide were viewed at $100 \mathrm{X}$. An estimate of relative percent by dry weight of each food taxon in the fecal samples was obtained by preparing the plant fragments on microscope slides and analyzing the slides according to the procedure described by Sparks and Malechek (1968).

Dietary similarity of cattle and deer on each area were estimated by Kulczynski's similarity index (Oosting 1956), the same method used by Hubbard and Hansen (1976), Hansen and Clark (1977), and Hansen et al. (1977). Hansen et al. (1973) reported that comparison of plant fragments in herbivore dung samples indicated diet overlap. Common and scientific names of plants are those suggested by Beetle (1970).

\footnotetext{
Authors were research associate and professor, Range Science Department, Colorado State University, Fort Collins 80523 . This study was supported in part by the CSU Experiment Station Project 1078.

Manuscript received June 11, 1979.
}

\section{Results}

Graminoids composed $75 \%$ of the cattle foods when averaged across all nine areas. Wheatgrasses (Agropyron) were the major taxon averaging 20\% (Table 1). Needlegrasses (Stipa) and dropseeds (Sporobolus) were also major cattle forages. Forbs and browse made up $99 \%$ of the mule deer foods (Table 1). True mountainmahogany (Cercocarpus montanus) was the most com mon taxon averaging 35\%. Sagebrushes (Artemisia), gambel oak (Quercus gambeli) and antelope bitterbrush (Purshia tridentata) were other important deer forages. Diet overlap between cattle and mule deer ranged from 1 to $22 \%(\mathrm{x}=12 \%)$ across the nine areas studied.

\section{Discussion}

When availability of a food resource decreases, animals will shift their diets to less preferred foods if the latter are more abundant (Emlen 1966, 1968). Nevertheless, diet overlap between competing herbivores is not significant from a management standpoint until a reduction in availability of forage caused by one herbivore decreases productivity of another herbivore. A substantial reduction in forage availability resulting from herbivory may occur in two possible ways: both herbivores may require large quantities of the limiting resource, or one herbivore may require only small amounts per individual but the stocking rate of this herbivore is high. Unfortunately, stocking rates of mule deer and cattle were not available for this study.

The average diet overlap between cattle and mule deer in this study was higher than that previously found in western Colorado (Hubbard and Hansen 1976; Hansen and Clark 1977: Hansen et al. 1977). On the four areas where diet overlap was greater than the mean for all nine areas, cattle feces contained $32 \%$ browse, with sagebrushes and gambel oak making up to 19 and $17 \%$ of some samples, respectively. On the other five areas browse made up 15\% of the cattle samples. About $10 \%$ browse has been reported in other

Table 1. Mean percentages ( \pm SE) of plant taxa in cattle and mule deer fecal samples collected on nine deer winter ranges in western Colorado in autumn, 1976.

\begin{tabular}{lcc}
\hline \hline Forage taxa & Cattle & Deer \\
\hline Agropyron & $20 \pm 4$ & $<1$ \\
Stipa & $13 \pm 2$ & $<1$ \\
Sporobolus & $10 \pm 4$ & $<1$ \\
Carex & $7 \pm 4$ & $<1$ \\
Atriplex & $7 \pm 1$ & $<1$ \\
Poa & $6 \pm 1$ & $<1$ \\
Koeleria & $6 \pm 2$ & $18 \pm 6$ \\
Artemisia & $6 \pm 2$ & $16 \pm 9$ \\
Quercus gambeli & $2 \pm 2$ & $35 \pm 9$ \\
Cercocarpus montanus & $1 \pm 1$ & $11 \pm 4$ \\
Purshia tridentata & $1 \pm 1$ & 20 \\
Others $^{1}$ & 21 & \\
\hline
\end{tabular}

IIncludes 26 and 31 taxa $(<5 \%)$ for cattle and mule deer, respectively. 
studies of cattle diets in western Colorado. We assume that cattle would consume $32 \%$ browse only on areas where the preferred grasses had been depleted. On the other hand, the deer foods on these four areas contained $1 \%$ graminoids and $86 \%$ browse. This percentage breakdown of forage types is similar to that found in other mule deer diet studies in western Colorado.

We believe that use of mule deer winter range by cattle at stocking rates compatible with graminoid production may increase the available browse for deer. But, overgrazing by livestock may force cattle to consume browse species utilized by deer. Also excessive cattle grazing does not shift deer diets away from the preferred browse species, but cattle will consume browse plants when preferred grasses become depleted. Further study is needed to determine if during periods of high deer density, deer consume greater quantities of grasses when browse becomes depleted as suggested by some early diet studies conducted when deer populations were high (Robinson 1931, 1937; Interstate Deer Herd Committee 1947).

\section{Literature Cited}

Beetle, A.A. 1970. Recommended plant names. Univ. Wyoming Agr. Exp. Sta. Res. J. 31, Laramie. 124 p.

Emlen, J.M. 1966. The role of time and energy in food preference. Amer. Natur. 100:611-617.
Emlen, J.M. 1968. Optimal choice in animals. Amer. Natur. 102:385-389.

Hansen, R.M. and R.C. Clark. 1977. Foods of elk and other ungulates at low elevations in northwestern Colorado. J. Wildl. Manage. 41:76-80.

Hansen, R.M., R.C. Clark, and W. Lawhorn. 1977. Foods of wild horses, deer, and cattle in the Douglas Mountain Area, Colorado. J. Range Manage. 30:116-118.

Hansen, R.M., D.G. Peden, and R.W. Rice. 1973. Discerned fragments in feces indicates diet overlap. J. Range Manage. 26:103-105.

Hubbard, R.E. and R.M. Hansen. 1976. Diets of wild horses, cattle, and mule deer in the Piceance Basin, Colorado. J. Rangc Managc. 29:389392

Interstate Deer Herd Committee. 1947. Second progress report on the cooperative study of the interstate deer herd and its range. California Fish Game. 33:287-314.

Oosting, H.J. 1956. The Study of Plant Communities. W.H. Freeman and Co., San Francisco. 440 p.

Robinson, C.S. 1931. Feeding habits and forage requirements of Rocky Mountain mule deer in the Sierra Nevada Mountains. J. Forest. 29:557564.

Robinson, C.A. 1937. Plants eaten by California mule deer on the I os Padres National Forest. J. Forest. 35:285-292.

Sparks, D.R., and J.C. Malechek. 1968. Estimating percentage dry weight in diets using a microscope technique. J. Range Manage. 21:264-265. 